\title{
防潮棟として建てられた軍艦島 VIBRATION SENSING OF BUILDING 31 号棟の振動センシング 31 BUILT AS WAVE-PROTECTIVE STRUCTURE IN GUNKANJIMA
}

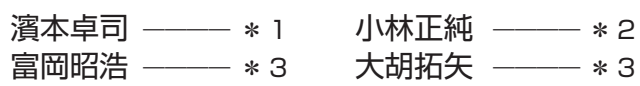

キーワード :

軍艦島モニタリング，振動センシング，31 号棟，台風，防潮棟， 衝撃作用

Keywords:

Gunkanjima monitoring, Vibration sensing, Building 31, Typhoon, Wave-protective structure, Impulsive action

1. はじめに

軍艦島の外周は，高波から島を守るために，防潮堤が $1.2 \mathrm{~km} に わ$ たり連続して屹立している。その高さは場所によって異なり, 外洋 となる西側では満潮面から 10～13m, 野母半島の見える東側では満 潮面から $5 \mathrm{~m}$ 程度である。しかし, 海が荒れると海水は防潮堤のはる か上を越えて島内に降り注ぐ。大型台風が島を襲うたびに防潮堤の 一部が破壊され，鉱区にも居住区にも甚大な被害が及んでいた1)。 台風接近時における軍艦島建築群の動的挙動に関しては，2015年8 月の台風15号が接近した際，島北部に位置する70号棟（洗堀孔埋戻 し前）の振動センシングにより得られた応答挙動を報告している2)。 軍艦島では, 海が荒れると防潮堤だけでは島を守り切る保証がで きないため, 多重防護の観点から, 防潮堤を第一の生命線とする様々 な防潮対策が施されていた ${ }^{3)}$ 。その一つが防潮棟という概念である。 防潮棟は，第二の防潮堤としての機能を担わせることを念頭に設計 された建物である。軍艦島で防潮棟として建てられた建物は, 31号 棟，48号棟，51号棟の3棟である。その中でも島南部に位置する31 号棟は防潮堤に沿って長く壁のように建てられている。1956年8月

\section{Takuji HAMAMOTO \\ Masazumi KOBAYASHI $-* 2$ Akihiro TOMIOKA — $* 3$ Takuya DAIGO — $* 3$}

Building 31 was constructed as one of the wave-protective buildings in Gunkanjima. High waves and strong winds have been often acting on the building during typhoons. High waves induce direct wave pressures and indirect ground vibrations propagating from adjacent seawalls. Strong winds generate positive and negative wind pressures. Dynamic behaviors of building 31 during two typhoons in 2018 were recorded by vibration sensor network. The dynamic behaviors during typhoons are investigated through long-time rms responses and short-time impulsive actions.
の台風9号は南西部の防潮堤を破壊し, その付近にあった木造商店 街を流し去った。31号棟はその跡地に建てられた。閉山後，1991 年9月の台風11号により南西部の防潮堤が破壊された際には，31号 棟に隣接する煉瓦造の映画館が崩壊した。防潮堤は31号棟の南側で 湾状に窪み, 波のエネルギーが集中しやすい場所になっている。

振動センシングのための建物の一つとして31号棟を選んだ理由 は，台風接近時に越波が直接作用したときの建物の動的挙動を記録 寸ることだった4)。2018年7月の台風7号は, 前述した台風に比べれ ば勢力は弱かったものの, その経路は1956年8月の台風9号に似てお り高波は防潮堤を越えた。さらに, 2018年10月の台風25号は五島列 島の西方海上を北上し, 軍艦島からはやや離れて通過したが, 勢力 の大きな台風であったため再び高波が防潮堤を越え, 島内の被害は 2018年中最大となった。本報では, 台風7号と台風25号における高 波が31号棟を直撃したときの動的挙動を検討する。

\section{2. 閉山前の状況と現状}

31号棟は，軍艦島居住区の南西側にあり，防潮堤に沿うように建

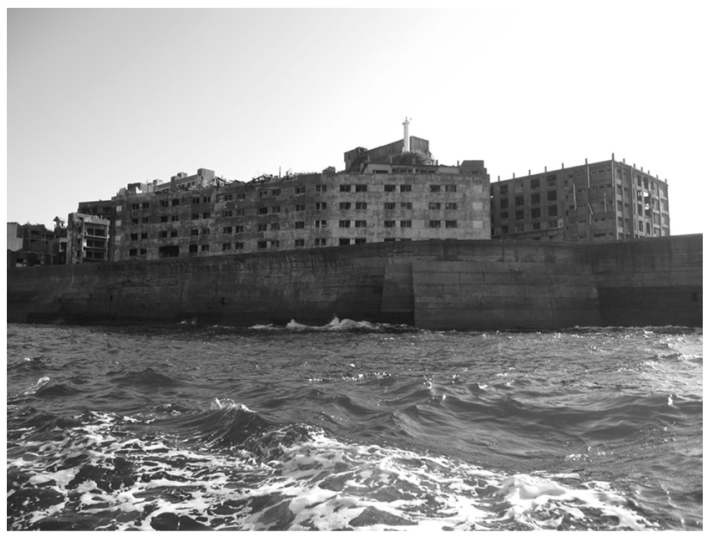

写真 1 船上から見た 31 号棟

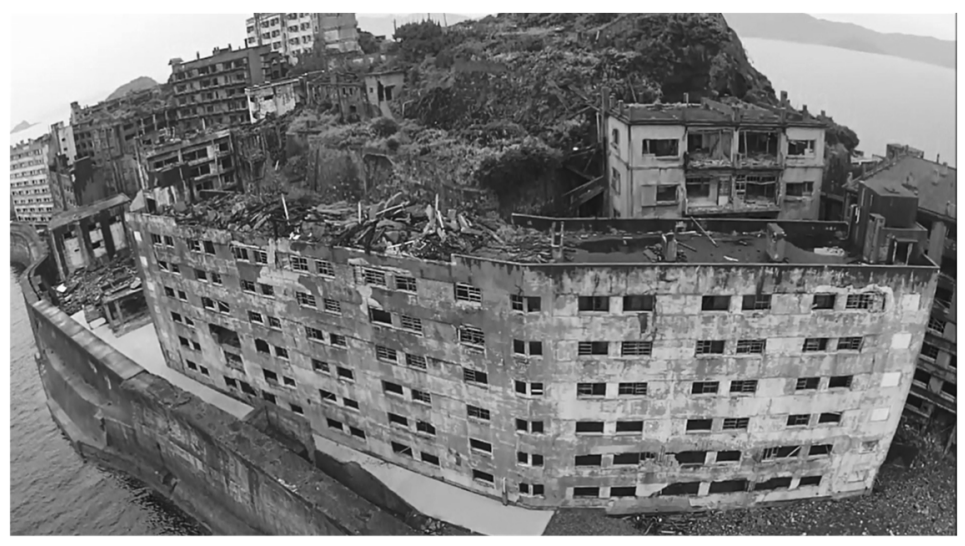

写真 2 ドローン空撮による 31 号棟

\footnotetext{
東京都市大学 名誉教授・工博

( 158-8557 東京都世田谷区玉堤 1-28-1)

大田区役所（元東京都市大学大学院生）

日本航空電子工業
} 

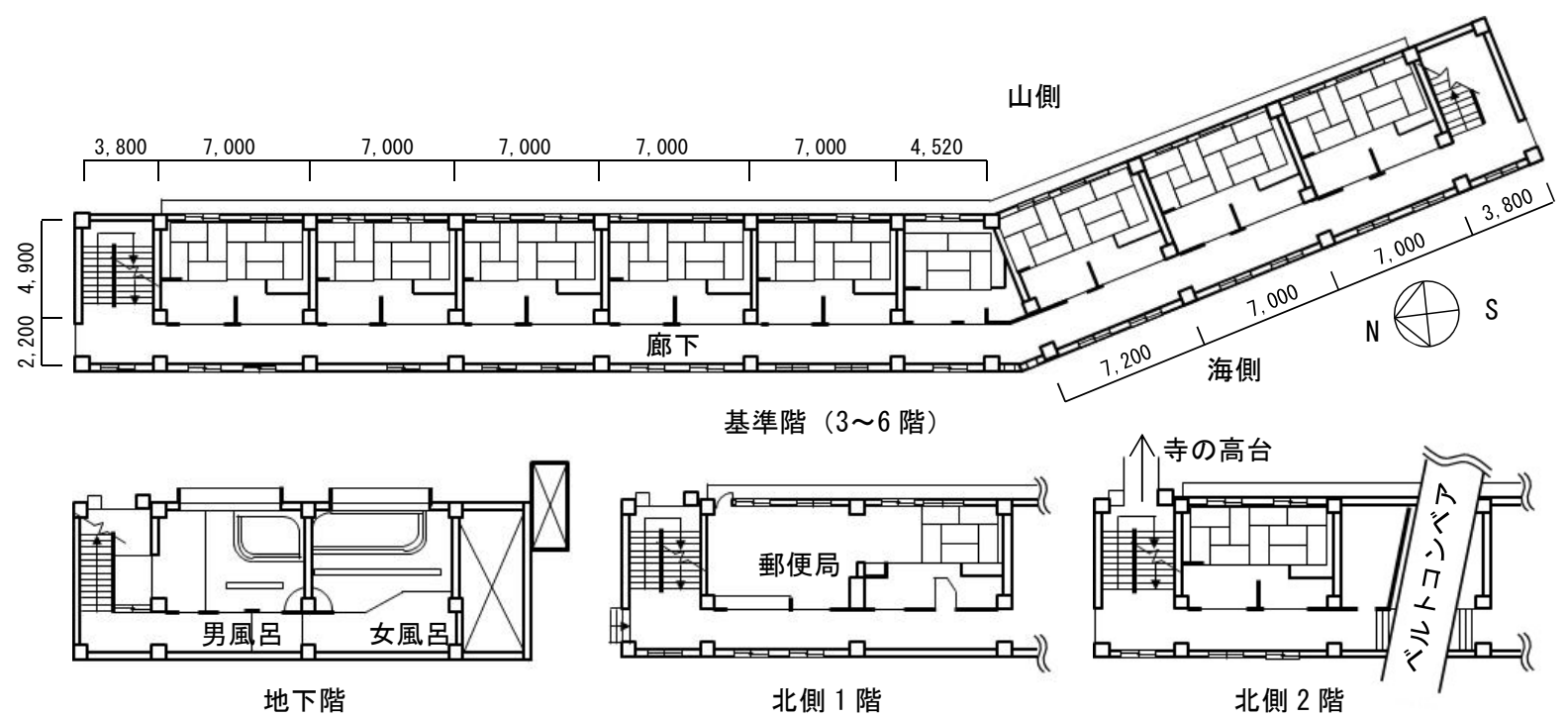

基準階（3～6 階）

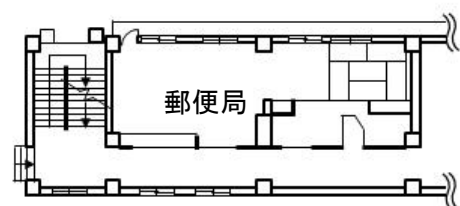

北側 1 階

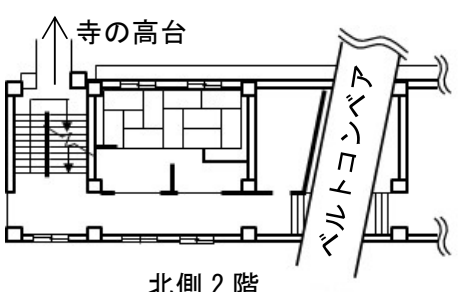

北側 2 階

図 1 平面図

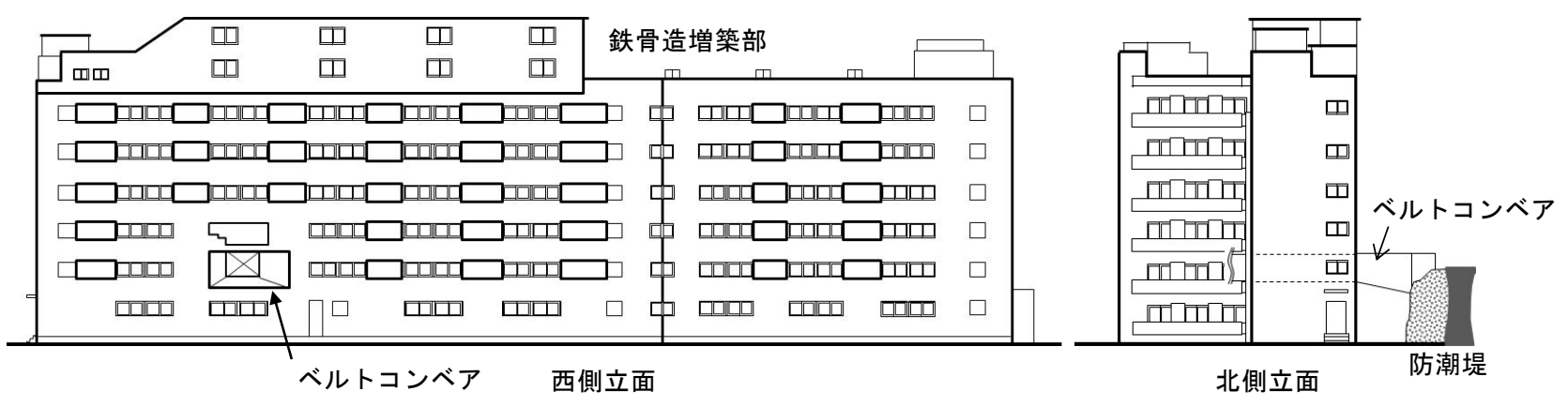

図 2 立面図(北側屋上鉄骨造 2 層の増築後)

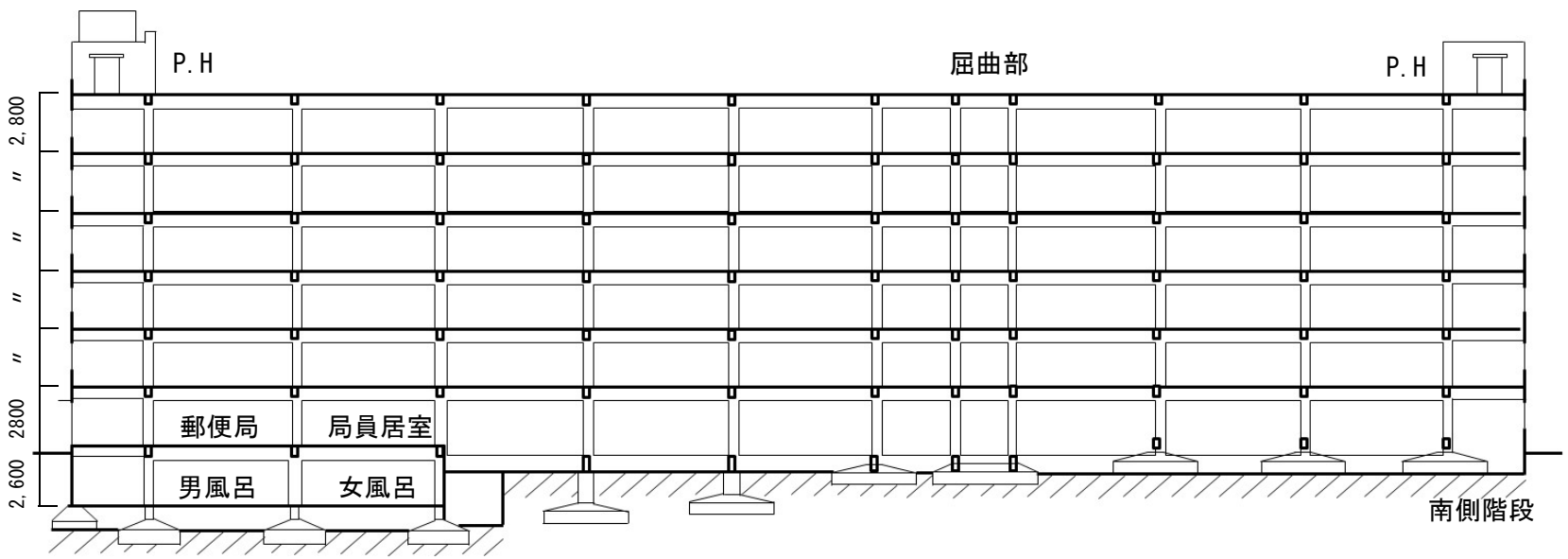

北側階段

図 3 架構図（鉄筋コンクリート造架構のみ）

てられた細長い「く」の字形平面の鉄筋コンクリート造6階建て・ 一部地下1階の鉱員アパートである。海から見上げた防潮堤と31号 棟を写真1に示す。竣工は1957年で, 島内では新しい建物に属する。 竣工後, 屋上北側には鉄骨ALC造2階分が増築され，一部8階建てに なった。しかし, 閉山後, 塩害により劣化して倒壊し, 現在は屋上 で瓦䃯となっている。ドローンから撮影した 31 号棟を写真2に示す。 鉄骨造部分増築後の基準階, 1階と2階の北側部分，および地下階の 平面図を図1に示寸。長い建物の北端と南端に出入口と階段がある。 北階段2階と3階の間の踊り場にも寺の高台へとつながる出入口が ある。居室のほかに, 1 階の北側には郵便局と局員居室, その地下
部分には共同浴場が設けられていた。西側（海側）と北側の立面を 図2に示す。2階の一部は, 鉱区から運ばれた石炭款を海上投棄する ためにベルトコンベアが貫通していた。架構図を図3に示す。岩盤 の高さに合わせてフーチングの高さが変化する直接基礎になってお り，床高は浸水に配慮して約1 $\mathrm{m}$ 上げられている。

防潮棟として建てられた31号棟は, 海側の長い廊下を緩衝地帯と して, 岩山側に居室を設ける平面計画を採用していた。岩山が急傾 斜で迫っているため低層階の住環境は恵まれていない。海側から作 用する波力に耐えるように, 居室間の戸境壁は厚さ約 $10 \mathrm{~cm}$ の耐力壁 になっている。海側の壁面は開口部を小さくした防潮壁であり, 開 


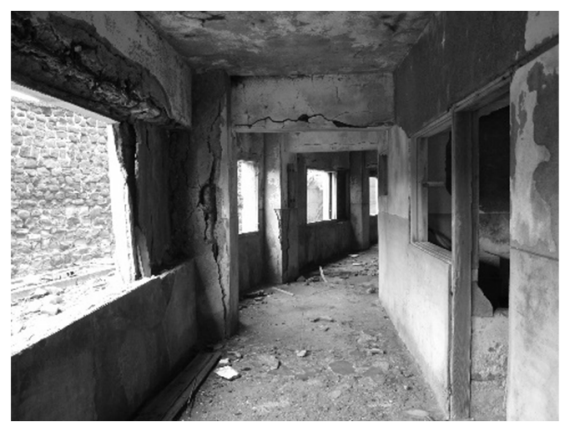

写真 31 階廊下屈曲部の損傷状態

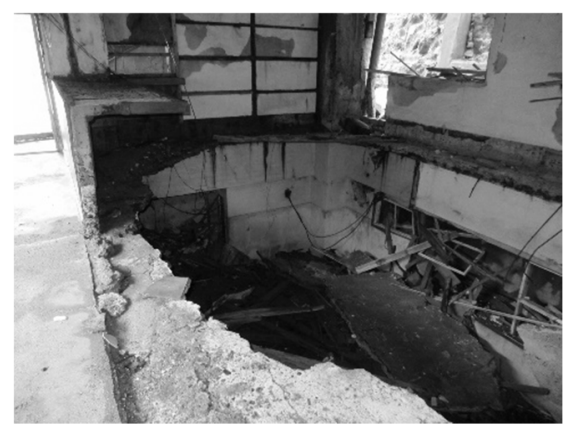

写真 6 台風時の 1 階床崩落部 (男風呂)

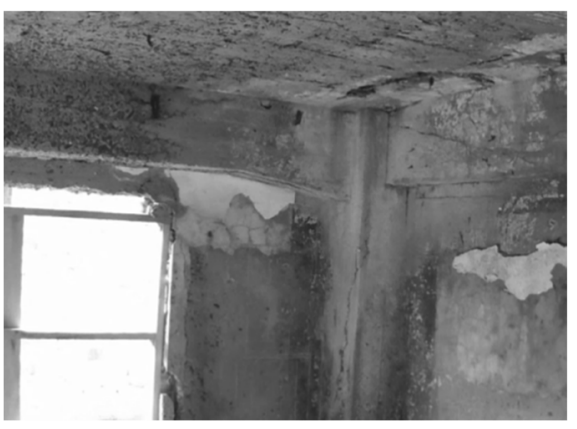

写真 4 居室山側の接合部の状態

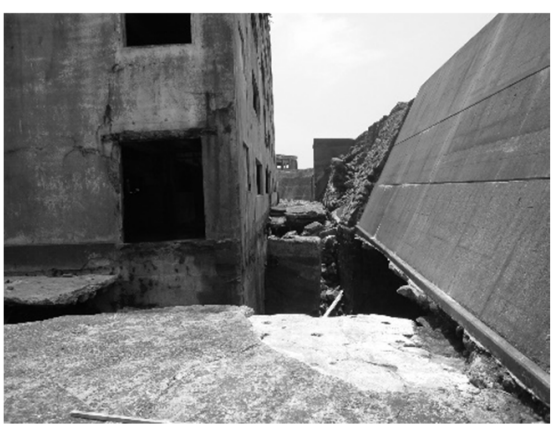

写真 731 号棟と防潮堤の間の洗堀

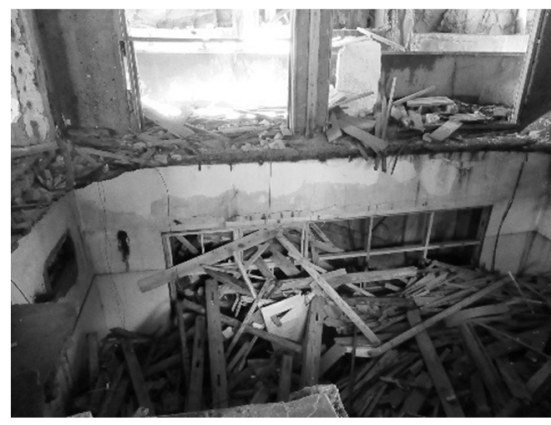

写真 5 台風前の 1 階床崩落部 (女風呂)

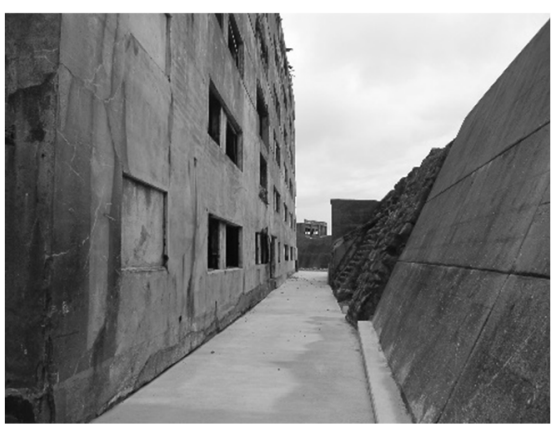

写真 8 洗堀部埋戻し後の状態
口部はそれぞれ木製厚板で閉鎖できるようになっていた。建物の入 口には木製の防潮扉を設け，庇と袖壁で防護する工夫が見られた。

閉山後, 空や入口は単なる開口となり, 写真3のように波と風に曝 された廊下の柱・梁の劣化・損傷がかなり進んでいる。それに比心゙ ると, 写真4のように, 山側の居室は柱・梁に廊下のような激しい ひびわれは見られず劣化・損傷の進行は遅い。地階の浴場は1階の 郵便局員居室床が崩落し, 写真5のように1階廊下から地下階（女風 呂）が見えていた。台風25号通過後は写真6のように隣接する郵便 局の床もコンクリート製のカウンター付近を除いて崩落し，地下階 （男風呂）が見えるようになった。防潮堤と 31 号棟の間の狭い通路 は, 栈橋から地下道を経て日給社宅や65号棟に向かう島のメインス トリートだった。しかし，閉山後は写真7のように防潮堤に穴が開 いて地盤が陥没し, さらに防潮堤を越えた波により深く洗堀されて 通行できなくなっていた。2014年8月の台風8号により防潮堤に大き な穴が空いたため, 防潮堤を修復し, 通路も写真8のように洗堀部 を瓦碩で埋戻し，現在はコンクリートで被覆して修復されている。

\section{3. 振動センサの設置}

31号棟に設置した振動センサの位置を図4に示す。長辺方向をx軸, 短辺方向をy軸, 高さ方向を $\mathrm{z}$ 軸とした。y方向は戸境壁に平行にとり, x方向はその直交方向である。31号棟は「く」の字形に屈曲してい るため, 北側と南側で座標系は異なっている。波の主方向はy方向に なる。振動センサは, 1階の北端部, 屈曲部, 南端部, および6階の 北端部, 屈曲部, 南端部に計6基を戸境壁と平行になるように設置 した。南端部の屋上ペントハウスにハブステーションを設け，6基 のセンサに通信ケーブルで並列配線した。31号棟計測用の電源とし て100ワットの太陽光パネルを屋上南側に設置した。太陽光パネル とハブステーションを電源ケーブルでつなぎ，ペントハウス外側に 設置したLTE通信用無線ルーターから携帯電話網につなげている。
計測時刻と計測時間は島外から制御できるようにした。静穏時は 2時間ごとに10分間の計測とし, 台風接近時は1時間ごとに10分間の 計測に切り替えた。サンプリング振動数は $200 \mathrm{~Hz}$, センサの計測レ ンジは $\pm 2 \mathrm{G}$, ノイズレベルは1 $1 \mu \mathrm{Grms}, A D$ 変換器の分解能は16bit である。AD変換器の入力レンジを $\pm 100 m G に$ 設定し計測を行った。

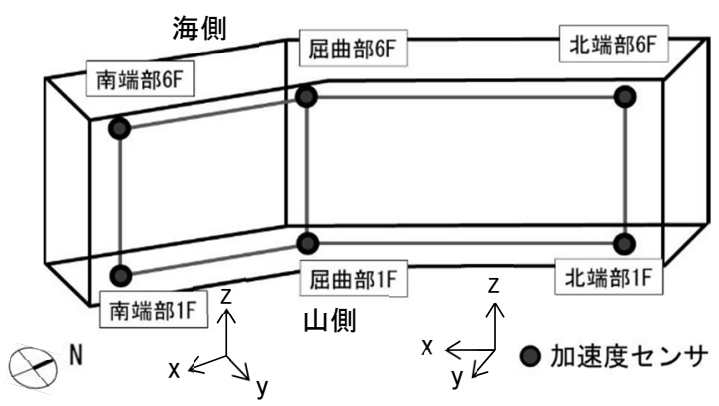

図 4 センサの設置位置

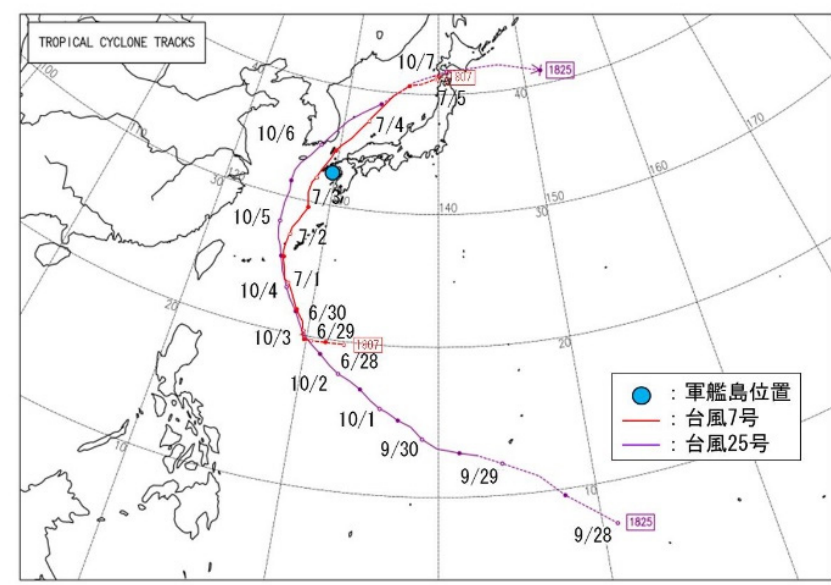

図 5 軍艦島に接近した 2 つの台風の経路 ${ }^{5)}$ 
4. 台風7号と台風25号

台風7号と台風25号の経路を図5に, 台風接近に伴う軍艦島近くで 記録された波高と風速の変化を図6に示す。波は軍艦島に最も近い

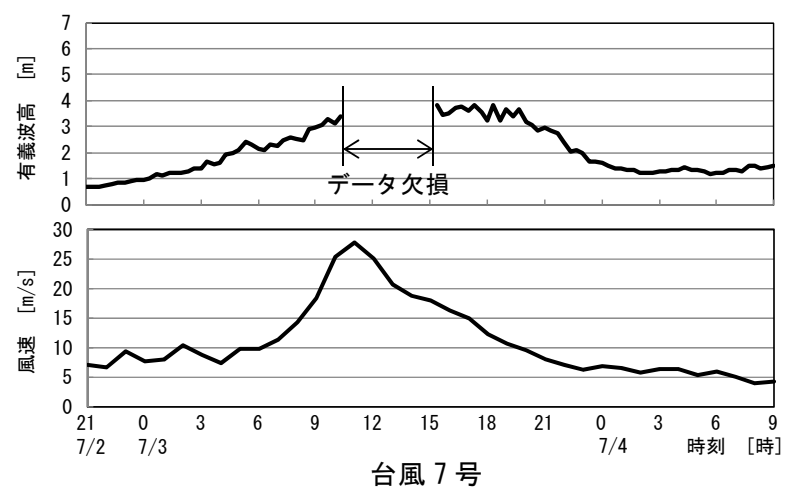

図 6 台風接近時の軍艦島周辺における海
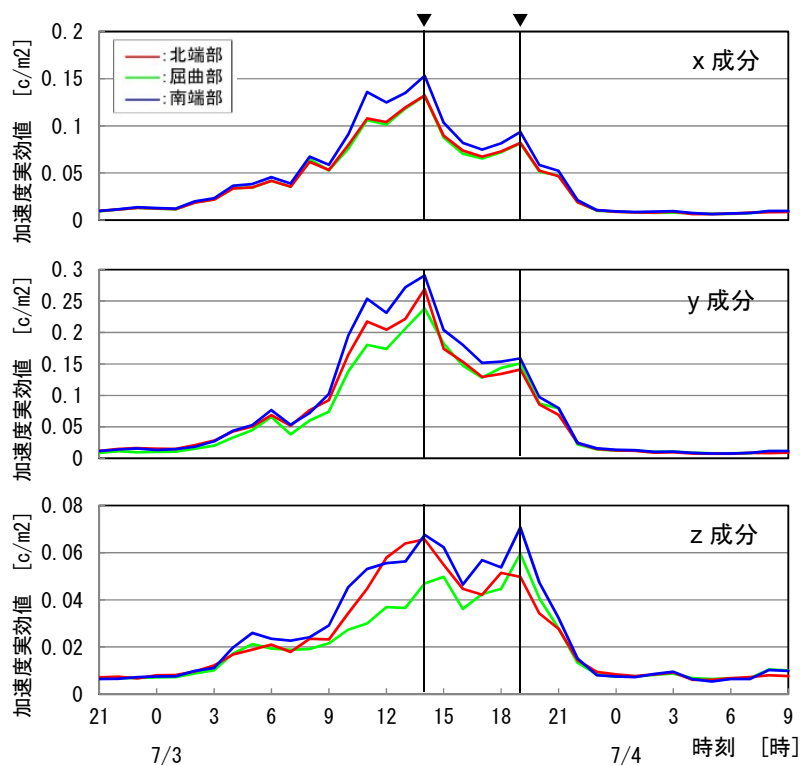

台風 7 号
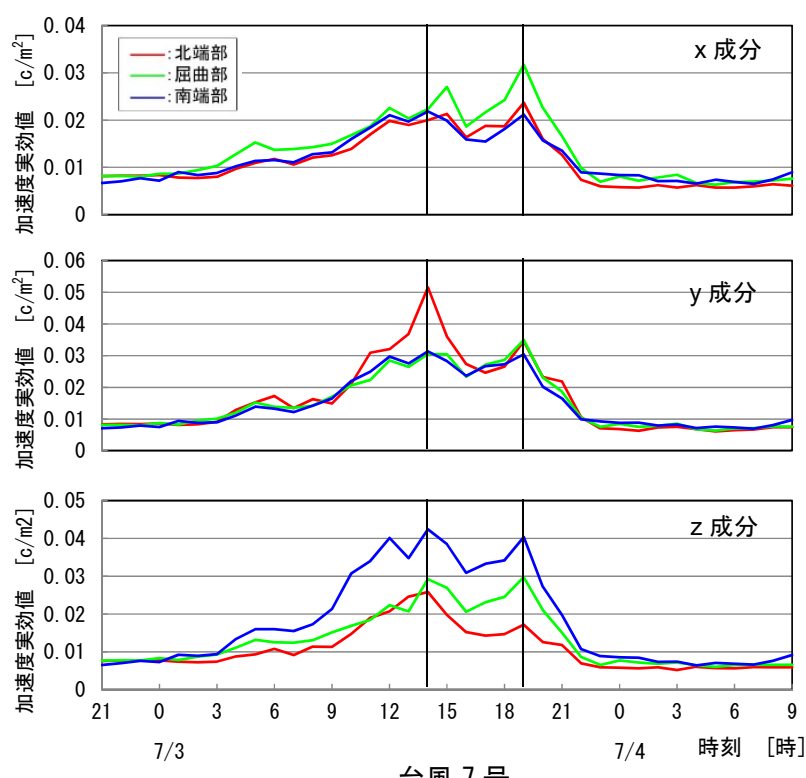

台風 7 号 波浪観測点である伊王島（約10km北方）の記録6)を，風は軍艦島に 最も近い気象観測点である野母崎（約5km南方）の記録7)を用いた。 台風7号の波高データには久損部がある。軍艦島近海において，両
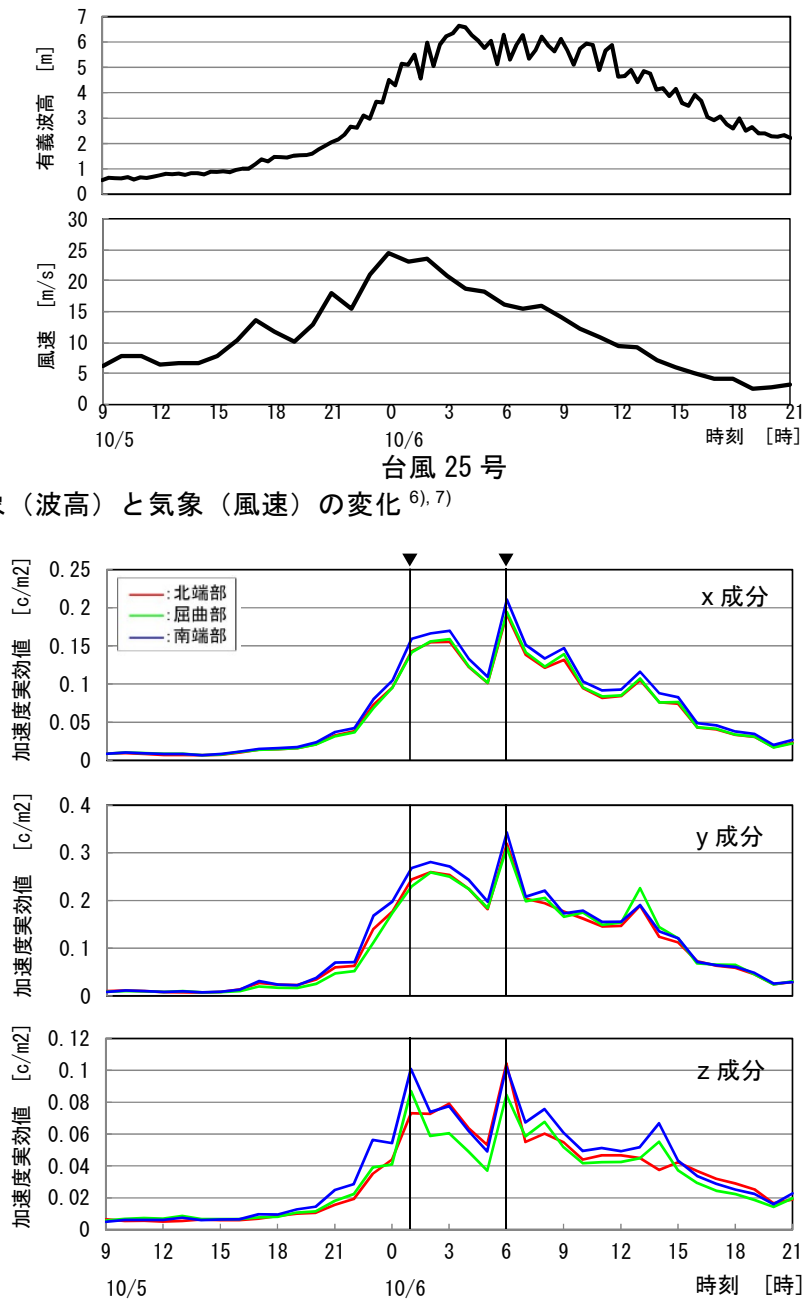

台風 25 号

(a) 6 階のセンサの位置
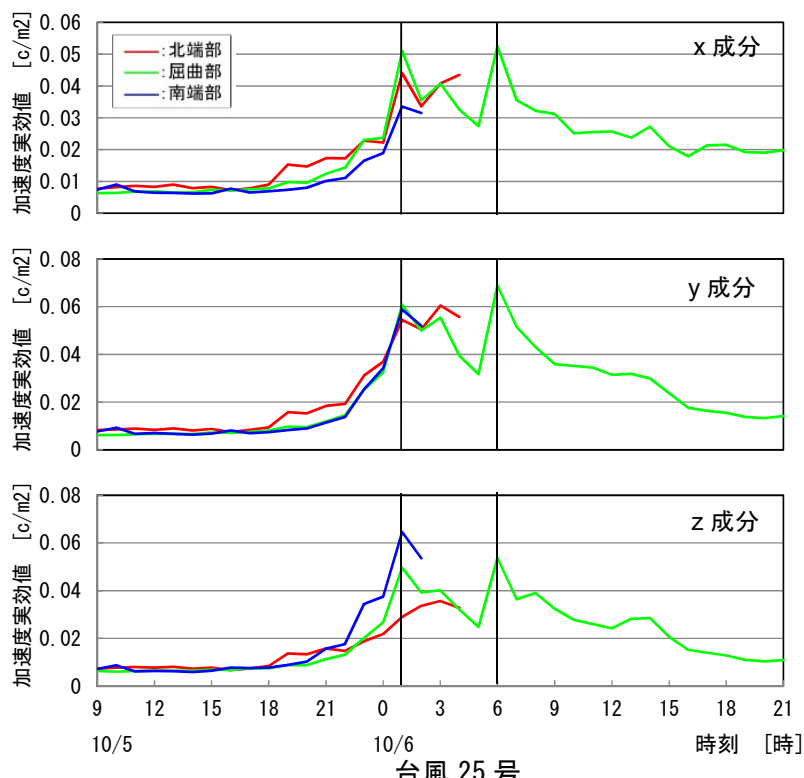

台風 25 号

(b) 1 階のセンサの位置

図 7 センサ位置における台風接近時の加速度実効值の変化 
台風の最大風速はほぼ同じになっているが, 台風25号のときの波高 は台風7号に比べると約1.5倍大きく, 台風7号の最大波高を超えて いた継続時間は約15時間になっている。

台風7号は, フィリッピンの東海上で発生し, 東シナ海を北上し て7月2日3時ころに久米島付近, 3日12時ころに五島列島付近（中心 気圧 $965 \mathrm{hPa}$, 最大風速 $30 \mathrm{~m} / \mathrm{s})$, 同日18時ころ対馬付近を通過し，4 日9時ころに日本海で温帯低気圧に変わった。軍艦島で最大風速 $27 \mathrm{~m} / \mathrm{s}$ を記録したのは7月3日11時ころだった。台風7号接近の際，島 内の見学通路の柵が倒れたり折れ曲がったりしたほか，栈橋の手摺 の一部が損壊するなどの被害が出た。

台風25号は，マリアナ諸島沖で発生し，10月4日21時に猛烈な勢 カでフィリピン東海上から沖縄本島と宮古島の間を抜けて東シナ海 に入り，6日3時ころに五島列島西方海上（中心気圧 $970 \mathrm{hPa}$, 最大 風速 $35 \mathrm{~m} / \mathrm{s}$ ）を通って, 朝鮮半島南岸をかすめるようにして日本海 に抜けた。軍艦島で最大風速 $25 \mathrm{~m} / \mathrm{s}$ を記録したのは10月6日0時ころ だった。軍艦島からは比較的離れた海域を通過したにもかかわらず, 台風の規模が大きかったため大時化（有義波高 $6 \mathrm{~m}$ 以上）になり島内 で大きな被害が発生した。上陸用栈橋のコンクリートが一部損壊し て手摺が倒れ, 見学通路には島内の石塊と瓦碩が押し寄せて埋め尽 くし, 通路沿いのほとんどの柵が倒れたり折れ曲がったりした。こ のため，2019年2月1日まで観光客の上陸禁止が続いた。

\section{5. 台風接近時の 31 号棟の動的挙動}

台風接近時のセンサ6基の位置における加速度時系列3成分の実

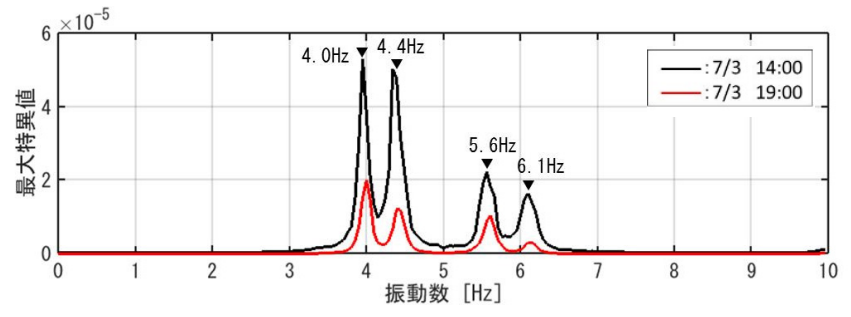

台風 7 号

図 8 特異值分解による台風接近時のモード抽出
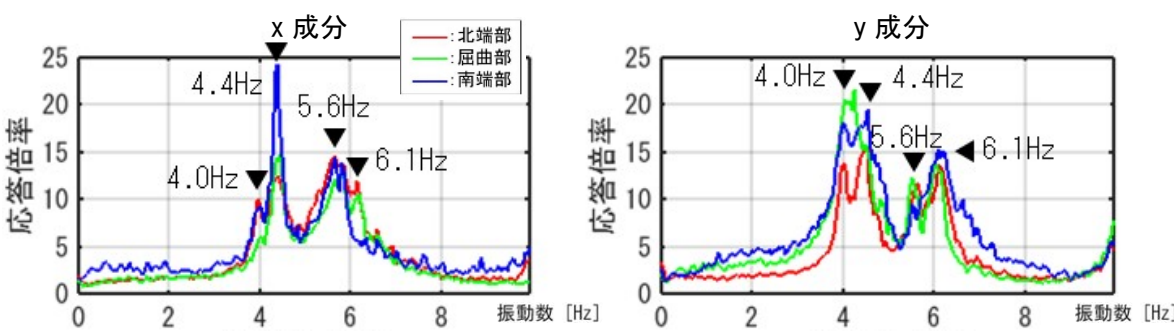

(a) 台風 7 号（7月 3 日 14:00）
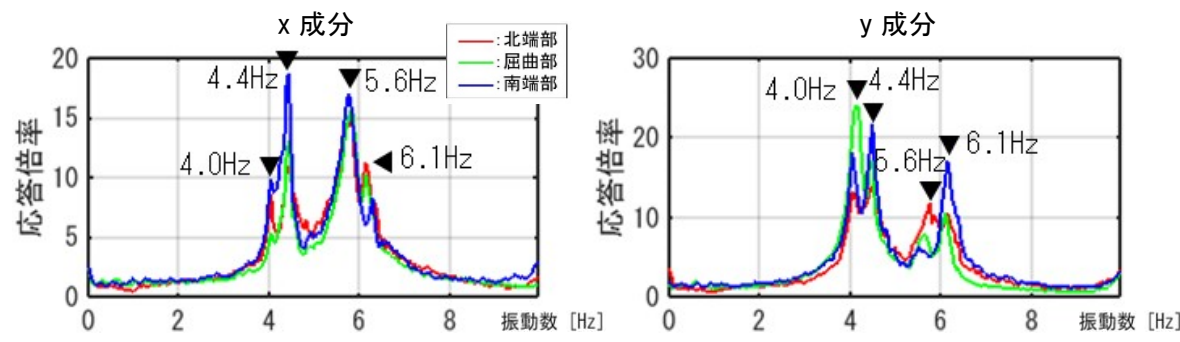

(b) 台風 25 号（10月6日 1:00）
効值（瞬時值10分間の2乗平均平方根）の変化を6階の3成分と1階の 3 成分に関して図7に示す。6階のx成分とy成分は台風7号接近時には 7月3日14:00, 台風25号接近時には10月6日6:00が最大になった。防 潮堤を常時打ちつける波が地盤振動を励起し, 防潮堤を時折越える 波が降り注ぐため，1階ではz成分が相対的に大きい。台風7号接近 時は7月3日14:00と19:00, 台風25号接近時は10月6日1:00にピーク がある。10月6日は，1階南端部で1:00過ぎ，1階北端部で3:00過ぎ にそれぞれセンサが機能停止した。1階南端部のセンサは保護カバ ーごと海水に流され，設置位置から約 $1 \mathrm{~m}$ 西側に移動していた。1階 北端部のセンサは設置床が大規模崩落し，かろうじて残存したもの のケーブル故障が生じた。図6と図7を比べると, 最大応答值は風速 が大きな時間帯ではなく, 波高が大きな時間帯に生じており, 台風 接近時の動的挙動は風速よりも波高に大きく影響されている。

台風7号接近時は7月3日14:00 と 19:00, 台風25号接近時は10月6 日1:00 6:00, 機能していた全センサの加速度時系列 $x, y, z$ 成分のパ ワースペクトルとクロススペクトルを用いて特異值分解を行った。 主要モードの固有振動数を抽出し図8に示す。台風7号, 台風25号と もに, $4 \mathrm{~Hz}$ 付近 $(4.0 \mathrm{~Hz}$ と $4.4 \mathrm{~Hz})$ に2つ, $6 \mathrm{~Hz}$ 付近 $(5.6 \mathrm{~Hz}$ と6.1 $\mathrm{Hz})$ に2つピーク振動数をもつ4つのモードが励起されている。4 $\mathrm{Hz}$ 付近 のピークは $6 \mathrm{~Hz}$ 付近のピークに比べて立ち上がりが明瞭である。 $6.5 \mathrm{~Hz}$ 以上の高次モードの励起は見られない。特異行列における最 大特異值の位置より，低振動数側から1番目のピークはy方向1次モ ード，2番目のピークはx方向1次モード，3番目のピークはx方向2次 モード，4番目のピークはy方向2次モードであることがわかった。

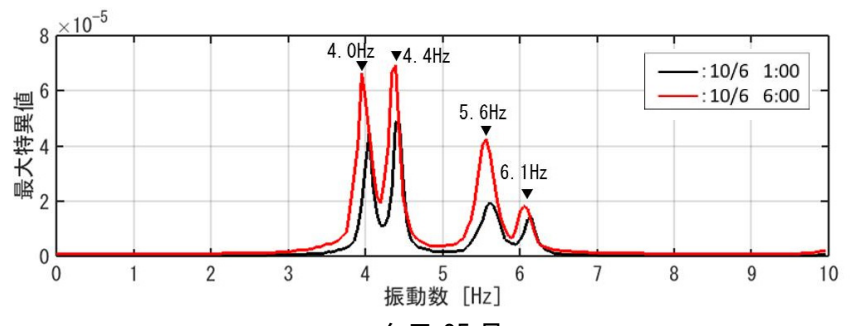

台風 25 号

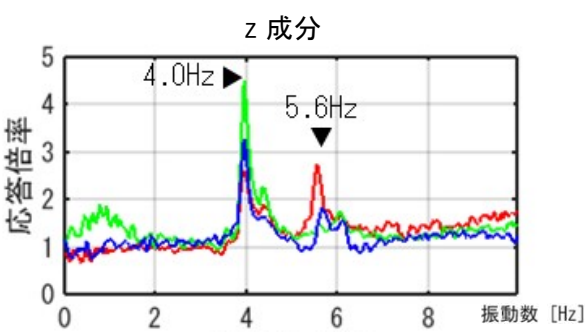

図 9 加速度スペクトル比による北端部・屈曲部・南端部における応答増幅の評価 

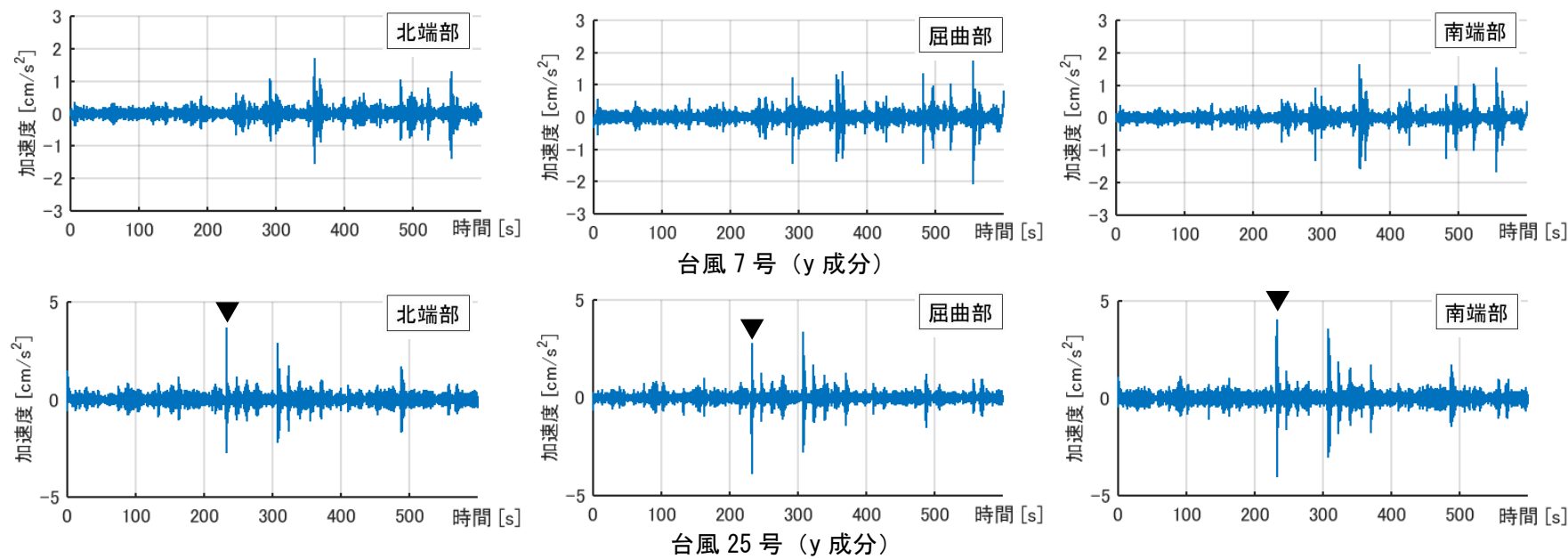

図 106 階で記録された加速度時刻歴波形
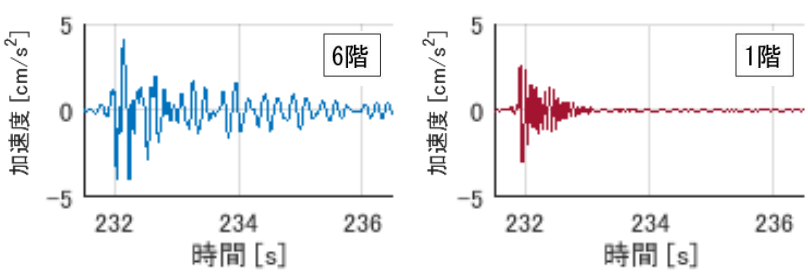

y 成分
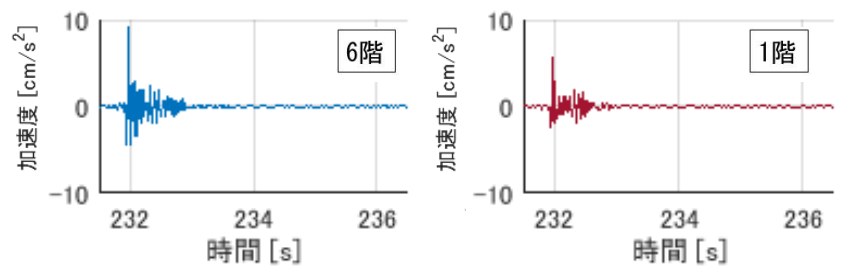

図 11 台風 25 号で最大パルスが発生したときの 6 階と 1 階の時刻歴波形の拡大

台風7号接近時は7月3日14:00, 台風25号接近時は10月6日1:00に おける北端部, 屈曲部, 南端部での加速度時系列各成分の1階に対 する6階のフーリエスペクトル比を図 9 に示す。いずれも各成分の増 幅率は $4 \mathrm{~Hz}$ 付近と6 $\mathrm{Hz}$ 付近で大きいが，卓越する振動数は計測位置 により異なっている。波の作用位置や屈曲形状, 地下階の有無, 屋 上の積載荷重の大小などの構造特性の違いによるものと考えられる。

台風7号と台風25号の接近時，加速度実効值がもっとも大きくな つた時間帯において，6階成分（波作用方向）の10分間時刻歴応答 波形を図10に示す。時刻歴にところどころ現れるパルス波は，防潮 堤を越えた高波が31号棟を直撃した衝撃荷重と考えられる。パルス 波は北端部，屈曲部，南端部で同時刻に発生しているが，その大き さは位置により異なっている。パルス波が最大になった位置の近く に高波が直撃した可能性が高い。時間軸を拡大して, 台風25号で最 大パルスが発生した時刻（図10に文で示した）における1階と6階の $\mathrm{y}$ 成分と $\mathrm{z}$ 成分の5秒間時刻歴波形を図11に示す。急激な立ち上がり と緩やかな減衰部からなる衝撃応答波形が確認できる。y成分では6 階が1階よりも緩やかに減衰している。屹立した防潮堤が波を上方 に跳水上げ，その海水が一気に降り注ぐため，z成分はy成分より大 きく，6階も1階もz成分の減衰は速い。高波が直撃するたびに，各 階では下から突き上げる摇れが生じていたことがわかる。

\section{6. 結び}

高波から島を守るために造られた防潮棟の一つである31号棟の 台風時挙動を，軍艦島に構築した振動センサネットワークの収録デ 一タに基づき検討し以下の知見を得た。

1) 最大応答值は波高が大きくなる時間帯に発生している。

2) 応答は短辺方向および長辺方向水平成分の1次と 2 次モードの寄
与が大きく，それより高次モードの寄与はほとんどない。

3) 波の作用位置や構造特性の違いにより, 北端部, 屈曲部, 南端部 の応答における各モードの寄与率は異なっている。

4) 波の直撃による衝撃作用はパルス波の発生として捉えられる。

5) 鉛直成分には水平成分より大きなパルス波が励起されている。

謝辞

本報告で紹介した軍艦島モニタリングは，科学研究費補助金基盤 研究(B)「想定外事象に対するネットワーク異常検知システムの軍艦 島における実証的研究 (研究代表者: 濱本卓司)」の補助を受けて行 われた。島内での機器設置と計測には長崎市の協力を得た。

\section{参考文献}

1) 後藤惠之輔，坂本道徳：軍艦島の遺産 風化する近代日本の象徵，長崎新 聞新書, 2005.4

2) 濱本卓司ほか: 台風通過時の軍艦島70号棟における振動センシング, 日本 建築学会技術報告集，Vol. 24, No.58, pp.101-106, 2018.10

3) 阿久井喜孝, 滋賀秀實 (編著) : 軍艦島 実測調査資料集, 東京電機大学出 版局, 1984.3

4) 濱本卓司ほか : 想定外事象に対する建築群変化検知システムの軍艦島にお ける実証実験, 日本建築学会技術報告集, Vol.24, No.57, pp.553-558, 2018.6

5) 気象庁ホームページ「台風経路図」, http://www.data.jma.go.jp/fcd/yoho/ typhoon/routemap/index.html，(参照 2019-2-27)

6) 全国港湾海洋波浪情報網（NOWPHAS）（国土交通省港湾局）, http://www.mlit.go.jp/kowan/nowphas/,（参照 2019-2-27）

7) 気象庁ホームページ「過去の気象データ・ダウンロード」, http://www.data.jma.go.jp/gmd/risk/obsdl/index.php,（参照 2019-2-27)

[2019 年 9 月 25 日原稿受理 2019 年 11 月 26 日採用決定］ 